\title{
The Impact of Corporate Governance Structure on the Efficiency Performance of Insurance Companies in Taiwan
}

\author{
Jennifer L. Wang ${ }^{\mathrm{a}}$, Vivian Jeng ${ }^{\mathrm{a}}$ and Jin Lung Peng ${ }^{\mathrm{b}}$ \\ ${ }^{a}$ Department of Risk Management and Insurance, National Chengchi University, Taipei, Taiwan. \\ E-mails: jenwang@nccu.edu.tw, vjeng@nccu.edu.tw \\ ${ }^{\mathrm{b}}$ Risk Management and Insurance Department, Shih Chien University, Taipei, Taiwan. \\ E-mail: jlpeng@mail.usc.edu.tw
}

The corporate governance system of the insurance industry in Taiwan, which holds board members fully responsible for cases of bankruptcy, offers an interesting environment in which to explore its unique regulatory impact on insurers' efficiency. Using a unique panel data from Taiwan, this paper investigates whether corporate governance variables - including insider ownership, voting rights, cash-flow rights, and board composition - influence the efficiency performance of insurance companies. The analysis suggests that a high concentration of voting rights and cash-flow rights in controlling shareholders' ownership has prevailed in Taiwan's insurance industry. Our overall evidence shows that corporate governance plays an important role in influencing efficiency for property-liability insurers in Taiwan. Specifically, insider ownership, cash-flow rights, and the presence of outside directors have positive impacts, whereas concentrated ownership, deviation between voting rights and cash-flow rights, board size, and the presence of CEO duality have negative impacts on insurers' efficiency.

The Geneva Papers (2007) 32, 264-282. doi:10.1057/palgrave.gpp.2510125

Keywords: corporate governance; efficiency performance; insurance industry; voting rights; cash-flow rights; board composition

\section{Introduction}

Corporate governance has been a topic of major interest in finance literature, specifically with regard to the question of why some firms perform better than others. Many finance studies show that the structure of corporate governance has crucial impacts on firm performance, but most of this previous literature investigates that relationship in industries other than financial services. In recent years, there has been increasing attention to the corporate governance issue in the worldwide financial services industry. With the passage of the Gramm-Leach-Bliley Act ${ }^{1}$ in late 1999, the financial services industry in the United States has been forced to cope with new

\footnotetext{
* The authors gratefully acknowledge the helpful comments of the editor, referees, and seminar participants at the 2004 ARIA meeting and APRIA conference.

${ }^{1}$ The Gramm-Leach-Bliley Act allows U.S. banks to enter the insurance business and mandates a greater reliance on internal corporate governance to control the actions of financial institutions.
} 
regulatory requirements. Specifically, as suggested by Booth et al. ${ }^{2}$ and Macey and $\mathrm{O}^{\prime} \mathrm{Hara}^{3}{ }^{3}$ the industry confronts a different set of agency costs and may lack adequate corporate governance controls as a result of the distinctive nature of its assets and liabilities, the special character of its ownership structure, fewer hostile takeovers, and the higher degree of financial leverage. Thus, empirical findings from non-financial services industries may not apply to financial service industries, though regulators, executives, investors, and policyholders must understand how corporate governance structure affects insurers' performance. In response, a special issue on corporate governance and corporate social responsibility in the Geneva Papers on Risk and Insurance 4 shed some new light and provided thought-provoking discussion on this issue. This article aims to extend that research using the corporate governance system of the insurance industry in Taiwan, which holds board members fully responsible for bankruptcies and thus offers a unique environment in which to explore regulatory impacts on insurers' efficiency. In so doing, this research provides a richer understanding of corporate governance structure's overall role in insurers' performance.

Berle and Means ${ }^{5}$ called world attention to corporate governance by investigating the implications of separating ownership and control over operations for corporations. They argued that, though the ownership of capital may be dispersed among small shareholders, control remains concentrated in the hands of managers. Their work has inspired many financial researchers. ${ }^{6}$ More recently, several other studies have considered empirical evidence about these issues; for example, Demsetz, ${ }^{7}$ Demsetz and Lehn, ${ }^{8}$ Shleifer and Vishny, ${ }^{9}$ Holderness and Sheehan, ${ }^{10}$ and Holderness et al. ${ }^{11}$ show that modern managerial ownership has increased significantly, which has led to higher overall firm value.

However, controlling management also entails a cost, especially agency costs derived from the fundamental conflicts between majority and minority shareholders' interests. John and Senbet, ${ }^{12}$ Short et al., ${ }^{13}$ and Berger et al. ${ }^{14}$ suggest that a higher level of managerial ownership may make it difficult to keep managers from engaging in directorial free-riding actions. Other researchers have examined corporate governance structure issues according to the concepts of voting rights ${ }^{15}$ and cash-flow

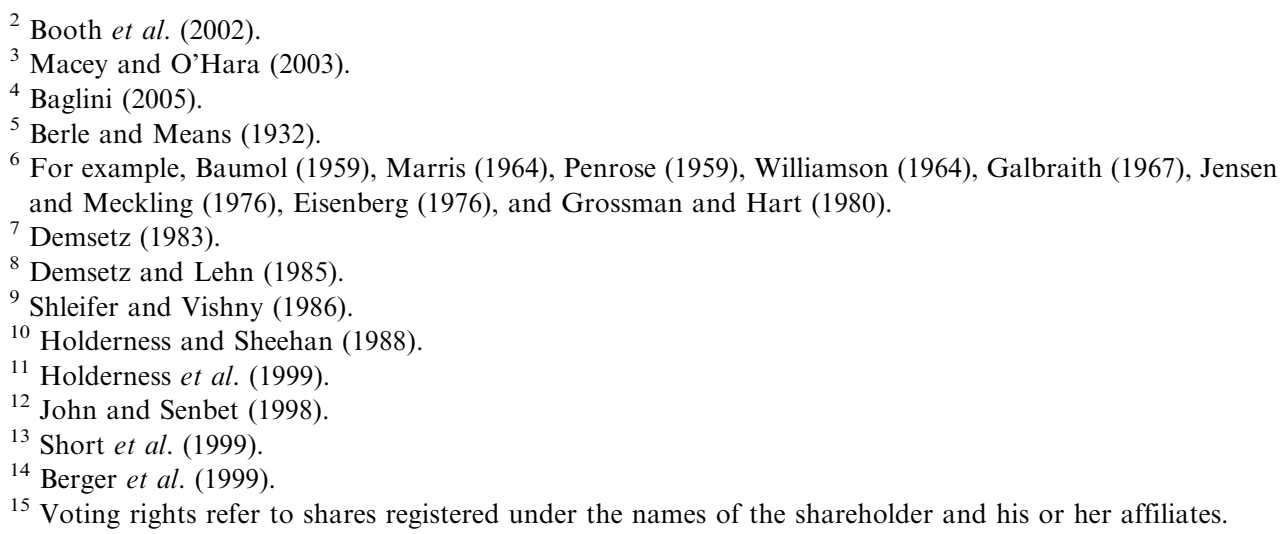


rights. ${ }^{16}$ La Porta et al. ${ }^{17}$ and Claessens et al. ${ }^{18}$ find that the greater the cash-flow rights of the largest shareholder, the better the firm's performance.

So what is the best corporate governance structure for minimizing agency costs? Extant literature also indicates that board composition plays an important role in influencing firm performance, with regard to determinants including board size, board activity, board independence, and insider ownership. We extend this line of research by linking the issue of corporate governance structure with efficiency performance in the insurance industry specifically and thereby investigate the following research questions: Does the concentration of managerial ownership prevail in the insurance industry? Does the corporate governance structure - and its elements such as managerial ownership, voting rights, cash-flow rights, and board composition - reflect important factors that influence the performance of insurance companies?

The corporate governance system in Taiwan offers a unique environment in which to study this issue. In Taiwan, large shareholders are often viewed positively, the frequency of independent outside directors is low, and external takeovers are extremely rare. Furthermore, the directors of the boards of insurance companies are, by law, held liable in the case of bankruptcy. These unique characteristics raise the question of whether corporate governance still plays an important role in influencing a firm's performance or whether other systems - such as holding board members legally liable - can serve as mechanisms for internal governance instead.

We use three-year (2000-2002) panel data from both the property-liability and life insurance industries in Taiwan to examine these issues and extend previous literature in several ways. First, ours is the first research to adopt the concept of voting rights and cash-flow rights to address corporate governance issues in the insurance industry, whereas previous literature ${ }^{19}$ has applied these concepts as proxies of corporate governance structures in non-financial services industries. By using the insurance industry as our research environment, we determine whether these proxies may perform differently in financial services industries. Second, in evaluating firm performance, we apply both traditional financial ratios and non-traditional measures, such as input/output efficiency measures, and employ the non-parametric approach of data envelopment analysis (DEA) to measure efficiency changes. No previous researchers have linked corporate governance, specifically managerial ownership proxies, with efficiency measures in insurance research. Third, as we suggested previously, our selection of the Taiwanese insurance market provides a different perspective for studying the effects of corporate governance, in that (1) regulations in Taiwan require unlimited liability for board directors, which may offer stronger support for the board's influence in preventing insolvency but likely is not necessary to improve insurers' efficiency performance, and (2) the life and property-liability insurers we examine involve a relatively high level of ownership concentration, mostly within family groups. Because ownership concentration may vary among different

\footnotetext{
${ }^{16}$ Cash-flow rights are the product of all ownership in the intermediate companies along the chain.

${ }^{17}$ La Porta et al. (2002).

${ }^{18}$ Claessens et al. (2002).

${ }^{19}$ For example, La Porta et al. (2002); Claessens et al. (2002).
} 
industries and countries, we believe our analysis provides greater insights in conjunction with previous research that focuses on large, non-financial services firms in relatively wealthy economies. ${ }^{20}$

With this approach, we reveal several significant empirical findings. Our overall evidence shows that corporate governance plays an important role in influencing the efficiency performance of property-liability insurers but not life insurance firms in Taiwan. In addition, we find that cash-flow rights, insider director ownership, and the presence of outside directors all have positive impacts, whereas concentrated ownership, deviations between voting and cash-flow rights, board size, and the presence of CEO duality have negative impacts on the efficiency performance of property-liability insurers in Taiwan.

The rest of this article is organized as follows: We discuss related literature and review our research hypotheses in the following section. In the next section, we describe the data and methodology. In the penultimate section, we conduct regression analyses of the relationships between corporate governance and insurers' efficiency performance. Finally, we conclude in the last section with a discussion of our findings.

\section{Related literature and research hypotheses}

Share ownership by directors and officers is an important component of corporate governance. On the basis of the convergence of interests hypothesis, ${ }^{21}$ Jensen and Meckling ${ }^{22}$ argue that as managerial ownership increases, a firm's performance improves. In contrast, according to the entrenchment hypothesis, Short et al. ${ }^{23}$ suggest that a high level of managerial ownership actually may increase an agency's problems in controlling managers' free-riding actions. Empirical results provided by John and Senbet $^{24}$ and Berger et al. ${ }^{25}$ also support Short et al.'s (1999) findings. Their studies suggest that a high level of managerial ownership increases the probability that managers will act to maximize their own interests, such as extending their tenure, ensuring their survival, or even increasing their bonuses. In summary, empirical evidence of the relationship between insider managerial ownership and firm performance remains contentious.

More recently, some researchers have extended this line of study by examining ownership of voting and cash-flow rights. La Porta et al. $^{26}$ and Claessens et al. ${ }^{27}$ argue that the greater the concentration of cash-flow rights in the hands of the largest shareholder, the greater is his or her incentive to run the firm properly. In addition,

\footnotetext{
${ }^{20}$ For example, La Porta et al. (2002).

${ }^{21}$ The convergence of interests hypothesis states that managers and directors take actions to protect their own wealth.

22 Jensen and Meckling (1976).

${ }^{23}$ Short et al. (1999).

24 John and Senbet (1998).

25 Berger et al. (1999).

${ }^{26}$ La Porta et al. (2002).

${ }^{27}$ Claessens et al. (2002).
} 
La Porta, et al., ${ }^{28}$ Claessens et al., ${ }^{29}$ and Faccio and Lang $^{30}$ point out that the controlling shareholders of publicly traded firms typically have voting rights that significantly exceed their cash-flow rights. Their empirical evidence suggests that the greater the deviation between voting rights and cash-flow rights, the greater is the negative entrenchment effect and the stronger the ultimate owners' incentive to protect minority interests.

In addition, existing literature has provided substantial evidence to indicate that boards of directors play important monitoring roles with regard to firm performance. Several factors may serve as important determinants of board effectiveness. The first key element is board size. Goodstein et al. ${ }^{31}$ and Firstenberg and Malkiel ${ }^{32}$ suggest that by increasing board size and becoming more diverse, boards help their firms link to external environments and thus obtain critical resources and a wider range of views to inform their corporate policy choices. Singh and Harianto ${ }^{33}$ indicate that larger board size may enhance corporate governance by reducing CEO domination, and Dalton et ll $^{34}$ find that larger boards increase firm performance. In contrast, increased board size may be less cohesive and thus result in poorer performance. ${ }^{35}$ Lipton and Lorsch, ${ }^{36}$ Jensen, ${ }^{37}$ and Eisenberg et al. $^{38}$ also suggest that large boards may increase agency problems, making them less effective in controlling management. Thus, empirical evidence regarding the relationship between board size and firm performance also remains mixed.

Board independence, measured as the percentage of outside directors, may represent another important factor for effective board monitoring. Fama and Jensen ${ }^{39}$ allege that outside directors act as managerial monitors because they have the incentive to protect their own reputations, and Rosenstein and Wyatt ${ }^{40}$ similarly find that appointments of outside directors may increase shareholders' wealth. However, Dalton et al. $^{41}$ and Bhagat and Black ${ }^{42}$ find no evidence that board independence increases firm performance. Once again, the empirical evidence is inconsistent regarding whether the presence of outside directors enhances a firm's performance.

Another potentially important factor is the presence of a CEO duality structure. In approximately 80 per cent of companies in the United States, the CEO also serves as the chair of the board. Jensen ${ }^{43}$ argues that this dual structure permits the CEO to

${ }^{28}$ La Porta et al. (1999).

${ }^{29}$ Claessens et al. (2000).

${ }^{30}$ Faccio and Lang (2002).

${ }^{31}$ Goodstein et al. (1994).

${ }^{32}$ Firstenberg and Malkiel (1994).

33 Singh and Harianto (1989).

34 Dalton et al. (1999).

${ }^{35}$ Cf. Shaw (1981), Kidwell and Bennett (1993), and Judge and Zeithaml (1992).

${ }^{36}$ Lipton and Lorsch (1992).

37 Jensen (1993).

${ }^{38}$ Eisenberg et al. (1998).

${ }^{39}$ Fama and Jensen (1983).

${ }^{40}$ Rosenstein and Wyatt (1990).

${ }^{41}$ Dalton et al. (1999).

42 Bhagat and Black (2002).

43 Jensen (1993). 
control the information available to board members and decreases the board's monitoring effect. This concentration of power may exacerbate potential conflicts of interest and thus create agency problems.

According to these previous findings, the existence of a relationship between corporate governance structure and firm performance is not clear a priori. We try to explore this conflict further by examining how corporate governance structure, which comprises managerial ownership, voting rights, cash-flow rights, and board composition, affects the performance of insurance companies. Our research hypotheses, which we provide as null statements, thus are as follows:

Hypothesis 1: No relationship exists between insider ownership and efficiency performance.

Hypothesis 2: No relationship exists between the cash-flow rights of the largest stockholders and efficiency performance.

Hypothesis 3: $\quad$ No relationship exists between the deviation between voting rights and cash-flow rights and efficiency performance.

Hypothesis 4: $\quad$ No relationship exists between board size and efficiency performance.

Hypothesis 5: No relationship exists between the percentage of outside directors and efficiency performance.

Hypothesis 6: No relationship exists between CEO duality and efficiency performance.

\section{Data and methodology}

To calculate the efficiency of insurance companies, we use input and output data from the Annual Statistical Report of Life Insurance and the Non-Life Insurance Review, respectively. Furthermore, to generate our corporate variables, including voting rights and cash-flow rights, we collect insurers' shareholder data from the annual statements insurers provide to regulators. We include three years of panel data, from 2000 to 2002, pertaining to 35 insurance providers. As of 2002, there were 54 insurers in Taiwan, including 28 life insurers and 26 property-liability insurers. We exclude nine life insurers and 10 property-liability insurers from our sample because they represent branch offices of foreign insurers and thus do not offer sufficient details about their corporate governance structure.

We specifically trace the voting and cash-flow rights owned by the largest shareholder for each firm, according to the ultimate control concept proposed by La Porta et al. ${ }^{44}$ Ownership by a family group (i.e., a group of people related by blood or marriage), rather than ownership by a single person, serves as the level of analysis, and we refer to the largest shareholder as the controlling shareholder; most controlling shareholders in Taiwan are families. To verify whether a group of people actually represents a family group, we search various information sources and documents for confirmation. Shareholding and the institutions controlled by these family-affiliated persons, in total, indicate the family's voting rights. The cash-flow rights of each

\footnotetext{
${ }^{44}$ La Porta et al. (1999).
} 


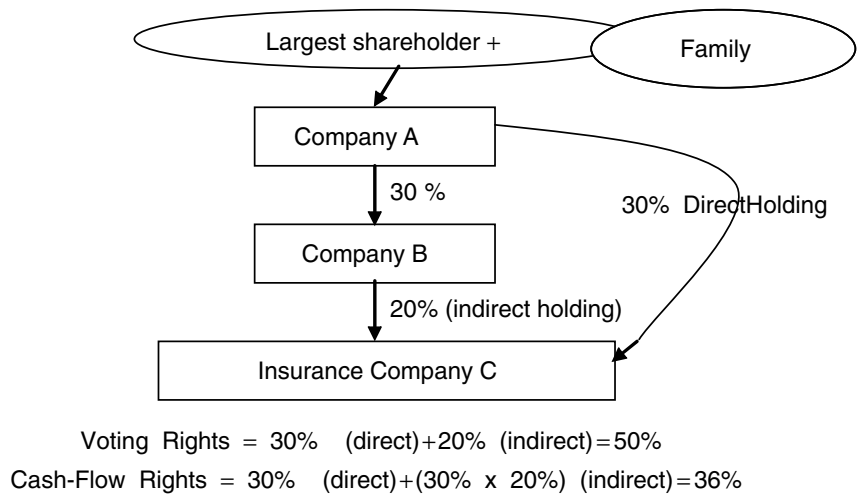

Figure 1. Voting rights and cash-flow rights.

family chain reflect the product of their ownership of intermediate companies along the chain, such that total cash-flow rights equal the sum of all cash-flow rights from all chains. For example, if Family A owns 30 per cent of Company B, which itself owns 20 per cent of Company C, then, as we demonstrate in Figure 1, Family A's control of the voting rights in Company $\mathrm{C}$ is 50 per cent, equal to 30 per cent of the direct holding plus 20 per cent of the indirect holding shares. The cash-flow rights that Family A generates from Company $\mathrm{C}$ are 36 per cent, which equals 30 per cent of the direct holding plus 6 per cent $(30 \% \times 20 \%)$ of the indirect holding shares.

However, we also note that, as in many countries, ownership information for family groups in Taiwan is difficult to obtain. Most of our valuable and publicly unavailable data related to corporate governance have been hand-collected, ${ }^{45}$ involving tremendous time and effort to gather from the Statutory Annual Statement that insurers deliver to regulators. Thus, our empirical evidence from this unique data set enables us to provide greater insights into and better analyses of the relationship between managerial ownership and insurers' performance.

For efficiency measures, there are two major classes of estimation approaches to measure efficiency: the econometric (parametric) approach and the mathematical programming (non-parametric) approach. ${ }^{46} \mathrm{We}$ employ a DEA approach a non-parametric approach - as our major methodology. In the following sections, we discuss our input/outputs proxies and calculation of three efficiency measures technical, allocative, and cost efficiency - that we use to evaluate the efficiency performance of life and property-liability insurers.

${ }^{45}$ One of the coauthors previously worked at the Ministry of Finance and the Insurance Commissioner's Office in Taiwan, which gave us access to more detailed ownership information. We are grateful to the Ministry of Finance and the Insurance Commissioner's Office for their assistance in collecting these valuable data.

${ }^{46}$ Cummins and Weiss (2000) discuss and summarize the advantages and disadvantages of these two approaches. 


\section{Inputs/outputs for life insurers}

In line with recent insurance and banking literature, ${ }^{47}$ we adopt the value-added DEA approach to measure outputs. As in most previous insurance literature, we define the output for life insurers as benefit payments and increases in policy reserves. Cummins et al $^{48}$ suggest that insurers provide three principal services: real services related to insured losses, risk-pooling and risk-bearing, and intermediation. We believe that benefit payments are useful proxies for the risk-pooling and risk-bearing functions, because they measure the amount of funds pooled by insurers and redistributed to policyholders as compensation. In addition, we select increases in the policy reserve as the output of the intermediation function. Both outputs correlate with real services provided by insurers, such as benefit administration in group insurance. We further disaggregate benefit payments into four categories: ${ }^{49}$ individual life insurance $\left(Y_{1}\right)$, personal accident insurance $\left(Y_{2}\right)$, individual health insurance $\left(Y_{3}\right)$, and group insurance $\left(Y_{4}\right)$. Finally, we deflate increases in policy reserves $\left(Y_{5}\right)^{50}$ to the base year 2001, using the consumer price index in Taiwan.

The inputs we use to calculate the efficiency measures include home office labor $\left(X_{1}\right)$, agent labor $\left(X_{2}\right)$, business services $\left(X_{3}\right)$, and equity capital $\left(X_{4}\right)$. Home office labor refers to the number of full-time home office employees, and the input price is equal to the home office expenses per person. Agent labor equals the number of agents, equal to the commission per person. The quantity of business services input reflects general insurance expenses divided by an expense deflator, which indexes the average monthly wages for business services industries in Taiwan. We interpret this expense deflator as the price of the business services input. Finally, we measure capital by the book value of the equity capital and the cost of capital by a firm's debtto-equity ratio. ${ }^{51}$

\section{Inputs/outputs for property-liability insurers}

Following previous insurance literature, we define outputs in the property-liability insurance industry as losses incurred and total invested assets. The losses incurred ${ }^{52}$

${ }^{47}$ See Yuengert (1993), Cummins et al. (1998).

${ }^{48}$ Cummins et al. (1998).

${ }^{49}$ Our analysis uses benefit payments reported in dollar amounts as outputs. As a robustness check, we also conducted the analysis using the number of benefit payments as outputs; this approach does not affect the results materially.

${ }^{50}$ We employ the increase in policy reserves as an additional output variable. Cummins et al. (1999) use the sum of the amount of benefit payments and addition to reserves, but we cannot follow this approach because we aggregate the increase in policy reserve from four different lines in Taiwan and thus cannot categorize them.

${ }^{51}$ In the context of corporate finance, $r_{E}=r_{A}+D / E \times\left(r_{A}-r_{D}\right)$, where $r_{E}$ is the price on equity, $r_{A}$ equals the return on assets, $r_{D}$ equals the return on debts, and $D / E$ is the debt-to-equity ratio. We assume that the return on assets is equal across firms in the same industry. If we further assume that the return on debt capital $\left(r_{D}\right)$ is the same across firms, the price of equity $\left(r_{E}\right)$ should be a function of a firm's debt-to-equity ratio.

${ }^{52}$ In the property-liability insurance industry in Taiwan, ceding business accounts for a significant percentage of the overall business for insurers, usually up to 30 per cent, depending on the insurance line. 
$\left(Y_{1}\right)$ represent risk-pooling and risk-bearing functions, and total invested assets $\left(Y_{2}\right)$ reflect the output of the intermediation function. For the inputs, following Cummins et al. ${ }^{53}$ we define four: labor $\left(X_{1}\right)$, business services $\left(X_{2}\right)$, debt $\left(X_{3}\right)$, and equity capital $\left(X_{4}\right)$. Because of the characteristics of businesses in the property-liability industry, we combine both home office labor and agent labor in a single labor input. Debt capital is the book value of the debt capital. We define the other inputs and input prices as we did for the life insurance industry. In Table 1, we provide descriptive statistics regarding the input and output variables, in which Panel A shows the statistics for the life insurance industry and Panel B shows those for the property-liability insurance industry.

The results in Panel A of Table 1 show that benefit payments for individual life and health insurance are the two major outputs for life insurance companies in Taiwan. In addition, when we compare the results of Panels $\mathrm{A}$ and $\mathrm{B}$, we find that the total outputs and labor (both home office and agent) in the life insurance industry are much greater than comparable measures in the property-liability insurance industry, and on average, the equity capital of life insurers (NT\$8,628,002) also is much greater than that of property-liability insurers (NT $\$ 4,735,861)$. Our results thus imply that the life insurance industry is relatively more dominant and mature than the property-liability insurance industry in Taiwan.

\section{Efficiency measures}

Existing DEA literature suggests that the efficiency of a firm consists of two components: (1) technical efficiency, which reflects a firm's ability to obtain maximal outputs from a given set of inputs, and (2) allocative efficiency, which reflects a firm's ability to use its inputs in optimal proportions, given their prices. We combine these measures to provide an overall measure of cost efficiency. ${ }^{54}$ All three efficiency measures vary between 0 and 1 , such that a score of 1 implies full efficiency. We base our approach on work by Farrell, ${ }^{55}$ Färe et al.,${ }^{56}$ and Cummins et al. ${ }^{57}$ Cummins and Weiss ${ }^{58}$ also provide an excellent review of the value-added approach and summarize the major efficiency studies in the insurance industry.

\section{Regression analysis}

To analyze further how corporate governance structure influences the performance of insurance companies in Taiwan, we conduct a regression analysis with financial

\footnotetext{
We first consider this output using both the amount of losses incurred-directly written and the amount of losses incurred-retained. Our results do not reveal any significant differences between the two, so we adopt the amount of losses incurred-retained as our first output.

${ }^{53}$ Cummins et al. (1999).

${ }^{54}$ Coelli (1996).

${ }^{55}$ Farrell (1957).

${ }^{56}$ Färe et al. (1985, 1994).

${ }^{57}$ Cummins et al. (1999).

${ }^{58}$ Cummins and Weiss (2000).
} 
Table 1 Outputs, inputs, and input prices used in efficiency analysis

\begin{tabular}{|c|c|c|c|c|c|}
\hline & & Mean & Std dev & Minimum & Maximum \\
\hline \multicolumn{6}{|c|}{ Panel A: Life insurance industry ${ }^{\mathrm{a}}$} \\
\hline \multicolumn{6}{|c|}{ Output } \\
\hline$Y_{1}$ & $\begin{array}{l}\text { Benefit payments, individual } \\
\text { life insurance }\end{array}$ & 132,687 & 210,154 & 1,138 & 807,280 \\
\hline$Y_{2}$ & $\begin{array}{l}\text { Benefit payments, personal } \\
\text { accident insurance }\end{array}$ & 49,726 & 92,543 & 13 & 359,775 \\
\hline$Y_{3}$ & $\begin{array}{l}\text { Benefit Payments, individual } \\
\text { health insurance }\end{array}$ & 104,267 & 180,618 & 435 & 857,908 \\
\hline$Y_{4}$ & $\begin{array}{l}\text { Benefit payments, group } \\
\text { insurance }\end{array}$ & 18,682 & 28,070 & 0 & 159,761 \\
\hline$Y_{5}$ & Increase in life policy reserve & $28,404,742$ & $50,926,814$ & 213,403 & $257,534,393$ \\
\hline \multicolumn{6}{|l|}{ Input } \\
\hline$X_{1}$ & Number of home office labor & 1,111 & 1,529 & 75 & 6,703 \\
\hline$X_{2}$ & Number of agent labor & 11,060 & 17,817 & 4 & 77,852 \\
\hline$X_{3}$ & Unit of business service & 5.28 & 9.38 & 0.33 & 39.21 \\
\hline$X_{4}$ & Equity capital & $8,628,002$ & $18,251,057$ & 13,295 & $88,159,880$ \\
\hline \multicolumn{6}{|c|}{ Input price } \\
\hline$P_{1}$ & Price of home office labor & 758,696 & 22,799 & 731,256 & 785,988 \\
\hline$P_{2}$ & Price of agent labor & 893 & 2,114 & 51 & 16,686 \\
\hline$P_{3}$ & $\begin{array}{l}\text { Average monthly wages for } \\
\text { business service industry }\end{array}$ & 50,622 & 1,606 & 48,448 & 51,840 \\
\hline$P_{4}$ & Price of capital & 50.46 & 164.65 & 0.38 & $1,229.93$ \\
\hline \multicolumn{6}{|c|}{ Panel B: Property-liability insurance industry ${ }^{\mathrm{b}}$} \\
\hline \multicolumn{6}{|c|}{ Output } \\
\hline$Y_{1}$ & Losses incurred & $1,624,790$ & $1,003,158$ & 190,059 & $5,151,330$ \\
\hline$Y_{2}$ & Investment & $7,256,544$ & $9,623,665$ & 679,648 & $50,253,571$ \\
\hline \multicolumn{6}{|l|}{ Input } \\
\hline$X_{1}$ & Number of labor & 779 & 430 & 376 & 2204 \\
\hline$X_{2}$ & Unit of business service & 1.58 & 0.98 & 0.75 & 5.16 \\
\hline$X_{3}$ & Debt & $7,669,410$ & $7,101,375$ & $2,027,956$ & $38,550,823$ \\
\hline$X_{4}$ & Equity capital & $4,735,861$ & $8,459,855$ & 253,309 & $39,828,384$ \\
\hline \multicolumn{6}{|c|}{ Input price } \\
\hline$P_{1}$ & Price of labor & 758,244 & 22,587 & 731,256 & 785,988 \\
\hline$P_{2}$ & $\begin{array}{l}\text { Average monthly wages for } \\
\text { business service industry }\end{array}$ & 50,674 & 1,592 & 48,448 & 51,840 \\
\hline$P_{3}$ & Price of debt & 0.035 & 0.017 & 0.008 & 0.071 \\
\hline$P_{4}$ & Price of capital & 3.08 & 3.49 & 0.78 & 24.77 \\
\hline
\end{tabular}

${ }^{\text {a }}$ For life insurance industry, other than inputs $X_{1}$ and $X_{2}$ and input prices $P_{3}$ and $P_{4}$, all outputs, inputs, and input prices are in units of NT\$1,000.

${ }^{\mathrm{b}}$ For property-liability insurance industry, other than input $X_{1}$ and input prices $P_{2}-P_{4}$, all outputs, inputs and input prices are in units of NT\$1,000. 
and efficiency performance as dependent variables and firm characteristics as the independent variables. We adopt three DEA efficiency measures to represent the efficiency performance of insurers - that is, technical efficiency $(T E)$, allocative efficiency $(A E)$, and cost efficiency $(C E)$ - as well as return on assets $(R O A)$ to serve as a proxy of financial performance. To test our hypothesis regarding the influence of insider ownership and cash-flow ownership, we include insider ownership (INSIDER) and cash-flow rights (CFR) variables in the regressions, such that positive coefficients imply that greater insider ownership and cash-flow rights improve insurers' performance. In addition, as we stated in the previous section, the deviation between voting rights and cash-flow rights may influence a firm's performance, so we examine this difference as well $(V R-C F R)$. To determine whether the board plays an important role, we include the four board composition variables - ownership concentration $(O W N C O N)$, board size (BOSIZE), board independence (BOIND), and CEO duality $(C E O D U A L)$ - that we deemed important for effective board monitoring in our regression.

Because the unique characteristics that may influence a firm's performance differ across industries, we further separate our regression analyses of life insurers and property-liability insurers and include specific control variables that may affect the different industries. ${ }^{59}$ For the life insurance industry, we include line concentration $(L B C)$, publicly traded information $(P U B)$, size $(S I Z E)$, and business mix (i.e., the proportion of a firm's premiums written for accident insurance $(A R)$, health insurance $(H R)$, and group insurance $(G R)$, excluding individual life insurance). For the property-liability insurance industry, we also add two variables, the reinsurance ratio $(R E I N S)$ and the proportion of written premiums in auto insurance (AUTO). Because ceding business accounts for a significant percentage of the overall property-liability insurance industry in Taiwan, the reinsurance ratio serves to control for the possible influence of reinsurance on a firm's performance. Finally, to control for the business mix, we consider the proportion of a firm's auto insurance premiums because the auto business is the dominant line in the property-liability insurance industry in Taiwan.

The regression model for the life insurance industry thus may be summarized as follows:

$$
\begin{aligned}
Y_{i}= & \beta_{0}+\beta_{1} * I N S I D E R_{i}+\beta_{2} * \text { CFR }_{i}+\beta_{3} *\left(V R_{i}-C F R_{i}\right) \\
& +\beta_{4} * O W N C O N_{i}+\beta_{5} * \text { BOSIZE }_{i}+\beta_{6} * \text { BOIND }_{i} \\
& +\beta_{7} * C E O D U A L_{i}+\beta_{8} * \operatorname{LBC}_{i}+\beta_{9} * P U B_{i} \\
& +\beta_{10} * \operatorname{SIZE}_{i}+\beta_{11} * A R_{i}+\beta_{12} * H R_{i}+\beta_{13} * G R_{i}+\varepsilon_{i}
\end{aligned}
$$

59 Two important variables - organizational form and distribution channel - do not appear in the regression model because there are no mutual insurers and no independent agency systems in the insurance market in Taiwan. 
The regression model for the property-liability insurance industry is as follows:

$$
\begin{aligned}
Y_{i}= & \beta_{0}+\beta_{1} * I N S I D E R_{i}+\beta_{2} * C_{C F R}+\beta_{3} *\left(V R_{i}-C F R_{i}\right) \\
& +\beta_{4} * O W N C O N_{i}+\beta_{5} * \text { BOSIZE }_{i}+\beta_{6} * \text { BOIND }_{i} \\
& +\beta_{7} * C E O D U A L_{i}+\beta_{8} * \text { LBC }_{i}+\beta_{9} * P U B_{i} \\
& +\beta_{10} * \operatorname{SIZE}_{i}+\beta_{11} * \operatorname{REINS}_{i}+\beta_{12} * A U T O_{i}+\varepsilon_{i}
\end{aligned}
$$

where $Y_{i}$ is the TE, AE, CE, or ROA; INSIDER is the insider ownership, or the percentage of shares owned by the director and officers; $C F R$ is the cash-flow rights; $V R-C F R$ is the difference between voting rights and cash-flow rights; $O W N C O N$ is the ownership concentration, or the percentage of shares owned by the 10 largest stockholders; BOSIZE is the board size, or the number of members on the board; $B O I N D$ is the board independence, or the percentage of outside directors among the board members; CEODUAL is the CEO duality dummy, which equals 1 if the CEO also serves as the chair of the board and 0 otherwise; $L B C$ is the line concentration, which equals the squared sum of each firm's individual business in relation to its total business, based on premium income; $P U B$ is the publicly traded dummy, which equals 1 if the firm is publicly traded and 0 otherwise; $S I Z E$ is the natural log of total assets; $A R$ is the percentage of premiums written for accident insurance; $H R$ is the percentage of premiums written for health insurance; $G R$ is the percentage of premiums written for group insurance; REINS is the reinsurance ratio, or the ratio of reinsurance premiums ceded to the sum of direct premiums written and reinsurance premiums; and $A U T O$ is the percentage of premiums written for auto insurance.

\section{Empirical results}

In this section, we present the results of our empirical analysis with regard to the summary statistics of the key variables applied in our analysis, including performance measures such as efficiency scores, ROA, and corporate governance. To investigate how corporate governance variables influence the performance of insurance companies in Taiwan, we then report our regression results to provide more insightful analyses.

In Tables 2 and 3, we report the performance measures and corporate governance variables for our sample firms in the life insurance and property-liability insurance industries, respectively. The technical efficiency scores for life insurers in Taiwan, on average, are approximately 0.871 , which implies that firms could have produced their outputs using 87.1 per cent of the inputs actually consumed. The allocative efficiency scores are 0.789 on average, somewhat lower than the technical efficiency scores, and therefore result in a cost efficiency score of 0.716 . The results for property-liability insurers suggest higher technical efficiency scores of 0.939 but similar allocative efficiency scores of 0.757 and cost efficiency scores of 0.719 . The financial performance measure, due mostly to an unprofitable return on recent capital markets, shows that ROA is lower for life insurers (-0.004) than for property-liability insurers $(0.024)$.

Our results also indicate insider ownership involves approximately 63 per cent of life insurers and 32 per cent of property-liability insurers in Taiwan. Compared with the 
The Geneva Papers on Risk and Insurance - Issues and Practice

276

Table 2 Descriptive statistics of variables for the life insurance industry

\begin{tabular}{|c|c|c|c|c|}
\hline & Mean & Std dev & Minimum & Maximum \\
\hline Technical efficiency (TE) & 0.871 & 0.196 & 0.307 & 1.000 \\
\hline Allocative efficiency (AE) & 0.789 & 0.225 & 0.154 & 1.000 \\
\hline Cost efficiency (CE) & 0.716 & 0.286 & 0.105 & 1.000 \\
\hline Return on assets (ROA) & -0.004 & 0.025 & -0.058 & 0.058 \\
\hline Insider ownership & 0.630 & 0.401 & 0.000 & 1.000 \\
\hline Voting rights & 0.732 & 0.264 & 0.296 & 1.000 \\
\hline Cash-flow rights & 0.537 & 0.307 & 0.170 & 1.000 \\
\hline Voting rights-cash-flow rights & 0.123 & 0.187 & -0.031 & 0.695 \\
\hline Ownership concentration & 0.872 & 0.198 & 0.210 & 1.000 \\
\hline Board size & 10.192 & 4.919 & 4.000 & 24.000 \\
\hline Board independence & 0.880 & 0.070 & 0.750 & 1.000 \\
\hline CEO duality & 0.096 & 0.298 & 0.000 & 1.000 \\
\hline Publicly traded dummy & 0.048 & 0.215 & 0.000 & 1.000 \\
\hline Line concentration & 0.616 & 0.119 & 0.295 & 0.862 \\
\hline Log of total asset & 17.347 & 1.752 & 13.862 & 20.975 \\
\hline$\%$ of premiums in accident insurance & 0.057 & 0.063 & 0.014 & 0.496 \\
\hline$\%$ of premiums in health insurance & 0.135 & 0.069 & 0.034 & 0.326 \\
\hline$\%$ of premiums in group insurance & 0.034 & 0.031 & 0.000 & 0.129 \\
\hline
\end{tabular}

Table 3 Descriptive statistics of variables for property-liability insurance industry

\begin{tabular}{|c|c|c|c|c|}
\hline & Mean & Std dev & Minimum & Maximum \\
\hline Technical efficiency (TE) & 0.939 & 0.085 & 0.614 & 1.000 \\
\hline Allocative efficiency (AE) & 0.757 & 0.175 & 0.406 & 1.000 \\
\hline Cost efficiency (CE) & 0.719 & 0.174 & 0.392 & 1.000 \\
\hline Return on assets (ROA) & 0.024 & 0.012 & 0.0006 & 0.064 \\
\hline Insider ownership & 0.323 & 0.455 & 0.000 & 1.000 \\
\hline Voting rights & 0.604 & 0.238 & 0.005 & 1.000 \\
\hline Cash-flow rights & 0.366 & 0.312 & 0.015 & 1.000 \\
\hline Voting rights-cash-flow rights & 0.234 & 0.226 & -0.091 & 0.789 \\
\hline Ownership concentration & 0.729 & 0.287 & 0.276 & 1.000 \\
\hline Board size & 11.435 & 4.943 & 5.000 & 21.000 \\
\hline Board independence & 0.944 & 0.059 & 0.833 & 1.000 \\
\hline CEO duality & 0.063 & 0.245 & 0.000 & 1.000 \\
\hline Publicly traded dummy & 0.479 & 0.505 & 0.000 & 1.000 \\
\hline Line concentration & 0.537 & 0.130 & 0.361 & 0.978 \\
\hline Log of total assets & 22.897 & 0.729 & 21.838 & 25.070 \\
\hline Reinsurance ratio & 0.567 & 0.131 & 0.192 & 0.835 \\
\hline$\%$ of premiums in auto insurance & 0.698 & 0.099 & 0.536 & 0.989 \\
\hline
\end{tabular}

average of 10 per cent in non-financial services firms, ${ }^{60}$ insider ownership of insurers in Taiwan is very high, especially in the life insurance industry. In addition, on average, voting rights are 82.1 per cent for life insurers and 60.4 per cent for property-liability

${ }^{60}$ For example, Yermack (1996); Vafeas (1999). 
Table 4 Regression results for property-liability insurers

\begin{tabular}{lcccc}
\hline Variables & $T E$ & $A E$ & $C E$ & $R O A$ \\
\hline Intercept & $2.550^{* * *}(2.82)$ & $1.613(0.90)$ & $2.434(1.56)$ & $-0.097(-0.46)$ \\
INSIDER & $0.132(1.37)$ & $0.342^{*}(1.80)$ & $0.362^{* *}(2.17)$ & $0.042^{*}(1.92)$ \\
CFR & $0.139^{* *}(2.31)$ & $0.269^{* *}(2.27)$ & $0.221^{* *}(2.13)$ & $-0.018(-1.16)$ \\
VR-CFR & $-0.277^{* * *}(3.42)$ & $-0.017(-0.11)$ & $-0.039(0.28)$ & $-0.013(-0.65)$ \\
OWNCON & $-0.160(-1.03)$ & $-0.628^{*}(-2.05)$ & $-0.627^{* *}(-2.34)$ & $-0.061(-1.74)$ \\
BOSIZE & $-0.003(-0.64)$ & $-0.010(-1.11)$ & $-0.013^{*}(-1.77)$ & $-0.002^{* *}(-2.32)$ \\
BOIND & $0.483(1.44)$ & $1.790^{* *}(2.70)$ & $1.705^{* * *}(2.94)$ & $0.199(2.07)$ \\
CEODUAL & $0.060(0.99)$ & $-0.234^{*}(-1.96)$ & $-0.015(-0.14)$ & $-0.021(-1.43)$ \\
LBC & $1.716^{* *}(2.45)$ & $1.266(0.92)$ & $2.380^{*}(1.97)$ & $0.037(0.44)$ \\
PUB & $-0.007(-0.24)$ & $-0.156^{* *}(-2.44)$ & $-0.151^{* *}(-2.71)$ & $-0.017 * *(-2.20)$ \\
SIZE & $-0.057^{*}(-1.81)$ & $-0.080(0.01)$ & $-0.092(-1.70)$ & $0.000(0.05)$ \\
RESINS & $-0.049(-1.11)$ & $0.001(-1.28)$ & $-0.064(-0.84)$ & $0.002(0.18)$ \\
AUTO & $-2.416^{* *}(-2.70)$ & $-1.385(-0.79)$ & $-2.857^{*}(-1.85)$ & $-0.030(-0.44)$ \\
Adj. $R$-square & 0.481 & 0.480 & 0.650 & 0.225
\end{tabular}

$* * *$ Significant at 1 per cent level of significance.

**Significant at 5 per cent level of significance.

*Significant at 10 per cent level of significance.

insurers; cash-flow rights are 53.7 per cent for life insurers and 36.6 per cent for property-liability insurers. Thus, according to results from previous literature, ${ }^{61}$ both voting rights and cash-flow rights variables also are higher for the Taiwanese insurance industry. Finally, the ownership concentration ratio is 87 per cent for life insurers and 73 per cent for property-liability insurers.

With regard to the board composition variables, our results show that there are, on average, 10-11 members on boards, smaller than the average board size of 12-14 members in non-insurer firms. ${ }^{62}$ Among these members, outsiders account for 88 per cent of life insurer boards and 94 per cent of property-liability insurer boards, whereas Yermack $^{63}$ and Vafeas ${ }^{64}$ document that the boards of non-financial services firms contain 52-56 per cent outside directors. Thus, it appears that board independence levels in Taiwanese insurers are high.

We employ Tables 4 and 5 to report the estimated parameters of the regression models and the corresponding $t$-statistics for the property-liability and life insurance industries, respectively. We test for multicollinearity using a variance inflation factor test and find that the assumptions of these regressions are not violated; the run test also is consistent with the hypothesis that no serial correlation exists at the 5 per cent level in the estimated equation. The adjusted $R$-squares in Tables 4 and 5 show that the overall goodness of fit of the regression is moderate, especially in the first three models, which apply efficiency measures as dependent variables.

From Table 4, we find that insider ownership relates positively to ROA, allocative efficiency, and cost efficiency for property-liability insurers. Moreover, the greater the

\footnotetext{
${ }^{61}$ For example, La Porta et al. (1999).

${ }^{62}$ For example, Chaganti et al. (1985); Yermack (1996).

63 Yermack (1996).

${ }^{64}$ Vafeas (1999).
} 
The Geneva Papers on Risk and Insurance - Issues and Practice

278

Table 5 Regression results for life insurers

\begin{tabular}{lcccc}
\hline Variable & $T E$ & $A E$ & $C E$ & $R O A$ \\
\hline Intercept & $0.145(0.17)$ & $0.181(0.18)$ & $-0.433(-0.31)$ & $-0.188(-1.23)$ \\
INSIDER & $-0.124^{*}(-1.89)$ & $-0.157^{*}(-2.03)$ & $-0.273^{* *}(-2.55)$ & $0.010(0.80)$ \\
CFR & $0.022(0.22)$ & $-0.169(-1.41)$ & $-0.183(-1.10)$ & $0.004(0.21)$ \\
VR-CFR & $0.134(0.95)$ & $-0.034(-0.21)$ & $0.134(0.58)$ & $-0.028(-1.11)$ \\
OWNCON & $-0.023(-0.17)$ & $0.204(1.28)$ & $0.165(0.75)$ & $0.003(0.14)$ \\
BOSIZE & $0.010(1.01)$ & $0.007(0.60)$ & $0.015(0.94)$ & $0.001(0.31)$ \\
BOIND & $-0.937(-1.42)$ & $-0.346(-0.44)$ & $-1.037(-0.96)$ & $-0.095(-0.77)$ \\
CEODUAL & $-0.083(-0.98)$ & $-0.064(-0.64)$ & $-0.029(-0.21)$ & $-0.0001(-0.01)$ \\
LBC & $0.152(0.35)$ & $0.053(0.11)$ & $0.211(0.30)$ & $-0.010(-0.13)$ \\
PUB & $0.037(0.36)$ & $0.126(1.03)$ & $0.122(0.73)$ & $-0.007(-0.37)$ \\
SIZE & $0.084^{* * *(3.55)}$ & $0.049 *(1.74)$ & $0.109 * * *(2.81)$ & $0.015^{* * *}(3.36)$ \\
AR & $-3.752^{*}(-1.81)$ & $-0.175(-0.07)$ & $-2.603(-0.77)$ & $-0.602(-1.61)$ \\
HR & $1.227 *(2.09)$ & $0.348(0.50)$ & $1.190(1.24)$ & $0.088(0.82)$ \\
GR & $-0.699(-0.75)$ & $-0.014(-0.01)$ & $-0.308(-0.20)$ & $0.042(0.24)$ \\
Adj. $R$-Square & 0.260 & 0.227 & 0.320 & 0.309 \\
\hline
\end{tabular}

$* * *$ Significant at 1 per cent level of significance.

** Significant at 5 per cent level of significance.

*Significant at 10 per cent level of significance.

cash-flow rights of the major shareholder, the better is the insurer's performance in terms of technical and cost efficiency for property-liability insurers. Thus, our empirical results support the convergence of interests hypothesis proposed by Jensen and Meckling. ${ }^{65}$ In addition, consistent with La Porta et al., ${ }^{66}$ Claessens et al. ${ }^{67}$ and Faccio and Lang, ${ }^{6}$ the greater the deviation between voting rights and cash-flow rights, the lower is the technical efficiency performance. Finally, allocative and cost efficiency both decrease as ownership concentration increases. In other words, the overall results reject our first three null hypotheses and confirm that ownership by insider directors, voting rights, and cash-flow rights are important determinants of firm performance for property-liability insurers in Taiwan.

Regarding the relationship between board composition and insurers' efficiency performance, we find a significant negative relationship, which implies that insurers with small boards achieve better performance in terms of ROA and cost efficiency. Furthermore, board independence relates positively to insurers' allocative and cost efficiency performance, and the presence of CEO duality decreases insurers' allocative efficiency performance. That is, the overall results reject our last three null hypotheses and imply that the composition of the board plays an important role in influencing property-liability insurers' performance in Taiwan.

We address the results for life insurers in Table 5 . The adjusted $R$-squares are relatively lower than those in Table 4 . In addition, we find a positive relationship

\footnotetext{
65 Jensen and Meckling (1976).

${ }^{66}$ La Porta et al. (1999).

${ }^{67}$ Claessens et al. (2000).

${ }^{68}$ Faccio and Lang (2002).
} 
between size and efficiency performance that suggests large firms are more efficient. However, we do not find significant results for most of the corporate governance proxies - in contrast with our results pertaining to property-liability insurers including cash-flow rights, the deviation between voting rights and cash-flow rights, and board independence. The only significant corporate governance proxy is the INSIDER variable, which, again in contrast with our findings for property-liability insurers, indicates a negative coefficient and thus implies that greater insider ownership decreases life insurers' efficiency.

The inconsistent results between the life and property-liability insurance industries provide meaningful implications. For example, we may not find a significant relationship between corporate governance proxies and firm performance for the life insurance industry because of its high ownership structure. As we show in Tables 2 and 3 , the corporate governance proxies between life and property-liability insurers are relatively different, including insider ownership ( 0.63 vs. 0.32$)$, voting rights $(0.732 \mathrm{vs.}$ $0.6)$, cash-flow rights ( 0.537 vs. 0.366$)$, and ownership concentration (0.872 vs. 0.729$)$. In related research, McConnell and Servaes ${ }^{69}$ find a significant curvilinear relationship between market-to-book ratios and insider ownership, such that as ownership by managers and directors becomes more concentrated, the firm's value first increases up to a certain point and then begins to decrease. We seem to observe a similar pattern in our empirical results. We find that a positive relationship exists between insider ownership and insurers' performance when the former is relatively low (e.g., 0.32 for property-liability insurers), but a negative relationship emerges when insider ownership grows relatively high (e.g., 0.63 for life insurers, almost double that for propertyliability insurers). In addition, because we find no significant relationship between firm performance and the other variables for life insurers, our empirical results seem to imply that as ownership in family groups becomes excessively dominant, as in the case of life insurers in Taiwan, other corporate mechanisms lose their functionality.

\section{Conclusions and discussion}

This research extends corporate governance literature by analyzing the impact of corporate governance structure on the efficiency performance of insurance companies in Taiwan. To our knowledge, we are the first to examine the effects of voting and cash-flow right ownership on efficiency performance. Furthermore, we provide several new contributions to insurance research by following two new perspectives. First, under the severe regulatory requirement that holds board members fully responsible for bankruptcies, the corporate governance system of the insurance industry in Taiwan offers an interesting environment to explore the distinct regulatory impact on insurers' efficiency performance. This unlimited responsibility may offer stronger support for the effect of the board's influence to prevent insolvency, but it also entails a trade-off between improving efficiency and preventing insolvency. Second, insurance firms in Taiwan have a relatively high level of ownership concentration, mostly within family

\footnotetext{
${ }^{69}$ McConnell and Servaes (1990).
} 
groups. Thus, we believe our empirical analysis adds significant insights to the literature pertaining to both corporate governance and efficiency performance issues.

Strikingly, our evidence demonstrates that corporate governance structure plays an important overall role in influencing insurers' performance in Taiwan. A high concentration of voting rights and cash-flow rights in controlling shareholder ownership has prevailed in Taiwan's insurance industry, though corporate governance variables generally affect efficiency performance for the property-liability insurers but not for life insurers.

For property-liability insurers, we find that insider ownership, cash-flow rights, and the presence of outside directors have positive impacts; concentration of ownership, deviations between voting rights and cash-flow rights, board size, and the presence of CEO duality have negative impacts. The empirical evidence from the life insurance industry, in contrast, is generally insignificant. The lack of a significant relationship between corporate governance structure and firms' performance among life insurers may result from the substantially high ownership holdings and concentration across life insurance companies. Thus, our results seems to imply that as ownership in family groups becomes overly dominant, as it has among life insurers, other corporate mechanisms lose their effects. In addition, the relationship between insider ownership and firm performance may be influenced by the control level of cash-flow rights, though we find opposite results for life insurers and property-liability insurers. Specifically, the relationship between insider ownership and firm performance is positive when insider ownership and cash-flow rights are relatively low (e.g., propertyliability insurers) but negative when insider ownership and cash-flow rights are relatively high (e.g., life insurers).

In summary, our findings provide new insights into the relationships between corporate governance structure and insurers' performance. However, the empirical results also demonstrate that corporate governance problems arising from different market structures and regulatory environments require further study. We hope that our empirical evidence thus encourages more studies that investigate the agencyprinciple conflicts in insurance companies and explore the crucial determinants of insurers' performance.

\section{References}

Baglini, N. (ed.) (2005) 'Special issue on corporate governance and corporate social responsibility', The Geneva Papers on Risk and Insurance - Issues and Practice 3: 353-497.

Baumol, W. (1959) Business Behavior, Value and Growth, New York: MacMillan.

Berger, A.N., Demsetz, R. and Strahan, P. (1999) 'The consolidation of the financial services industry: Causes, consequences, and implications for the future', Journal of Banking and Finance 23: 135-194.

Berle, A. and Means, G. (1932) The Modern Corporation and Private Property, New York: MacMillan.

Bhagat, S. and Black, B. (2002) 'The non-correlation between board independence and long-term firm performance', Journal of Corporation Law 27: 227-273.

Booth, J., Cornett, M. and Tehranian, H. (2002) 'Boards of directors, ownership, and regulation', Journal of Banking and Finance 26: 1973-1996.

Chaganti, R., Mahajan, V. and Sharma, S. (1985) 'Corporate board size, composition, and corporate failures in the retailing industry', Journal of Management Studies 22: 400-417.

Claessens, S., Djankov, S., Fan, J. and Lang, L. (2002) 'Disentangling the incentive and entrenchment effects of large shareholdings', Journal of Finance 58: 2741-2771. 
Claessens, S., Djankov, S. and Lang, L. (2000) 'The separation of ownership and control in East Asian corporation', Journal of Financial Economics 58: 81-112.

Coelli, T. (1996) A guide to DEAP Version 2.1: A data envelopment analysis program, working paper, University of New England, Armidale, Australia.

Cummins, J.D., Tennyson, S. and Weiss, M.A. (1998) 'Consolidation and efficiency in the U.S. life insurance industry', Journal of Banking and Finance 23: 325-357.

Cummins, J.D. and Weiss, M.A. (2000) 'Analyzing firm performance in the insurance industry using frontier efficiency and productivity approaches', in G. Dionne (ed) Handbook of Insurance, Boston: Kluwer Academic Publishers, pp. 767-829.

Cummins, J.D., Weiss, M.A. and Zi, H. (1999) 'Organizational form and efficiency: The coexistence of stock and mutual property-liability insurers', Management Science 45: 1254-1269.

Dalton, D., Daily, C., Johnson, J. and Ellstrand, A. (1999) 'Number of directors and financial performance: A meta-analysis', Academy of Management Journal 42: 674-686.

Demsetz, H. (1983) 'The structure of ownership and theory of the firm', Journal of Law and Economics 26: 375-390.

Demsetz, H. and Lehn, K. (1985) 'The structure of corporate ownership: Causes and consequences', Journal of Political Economy 93: 1155-1177.

Eisenberg, M. (1976) The Structure of the Corporation: A Legal Analysis, Boston: Little, Brown and Co.

Eisenberg, T., Sundgren, S. and Wells, M.T. (1998) 'Larger board size and decreasing firm value in small firms', Journal of Financial Economics 48: 35-54.

Faccio, M. and Lang, L. (2002) 'The separation of ownership and control: Analysis of ultimate ownership in Western European corporations', Journal of Financial Economics 65: 365-395.

Fama, E.F. and Jensen, M.C. (1983) 'Separation of ownership and control', Journal of Law and Economics 26: 301-325.

Färe, R., Grosskopf, S. and Lovell, C.A.K. (1985) The Measurement of Efficiency of Production, Boston: Kluwer-Nijhoff.

Färe, R., Grosskopf, S. and Lovell, C.A.K. (1994) Production Frontiers, New York: Cambridge University Press.

Farrell, M.J. (1957) 'The measurement of productive efficiency', Journal of the Royal Statistical Society A 120: $253-281$.

Firstenberg, P.B. and Malkiel, B.G. (1994) 'The twenty-first century boardroom: Who will be in charge?', Sloan Management Review 36(1): 27-35.

Galbraith, J.K. (1967) The New Industrial State, Boston: Houghton-Mifflin.

Goodstein, J., Gautam, K. and Boeker, W. (1994) 'The effects of board size and diversity on strategic change', Strategic Management Journal 15: 241-250.

Grossman, S. and Hart, O. (1980) 'Takeover bids, the free-rider problem and the theory of the corporation', Bell Journal of Economic 11: 42-46.

Holderness, C., Kroszner, R. and Sheehan, D. (1999) 'Were the good old day that good? Changes in managerial stick ownership since the great Depression', Journal of Finance 54: 435-469.

Holderness, C. and Sheehan, D. (1988) 'The role of majority shareholders in publicly held corporations: An exploration analysis', Journal of Financial Economics 3: 305-360.

Jensen, M.C. (1993) 'The modern industrial revolution, exit, and the failure of internal controls', Journal of Finance 48: 831-880.

Jensen, M.C. and Meckling, W.H. (1976) 'Theory of the firm: Managerial behavior, agency costs, and ownership structure', Journal of Financial Economics 3: 305-360.

John, K. and Senbet, L. (1998) 'Corporate governance and board effectiveness', Journal of Banking and Finance 22: 371-403.

Judge, W. and Zeithaml, C. (1992) 'Institutional and strategic choice perspectives on board involvement in the strategic decision process', Academy of Management Journal 35: 766-794.

Kidwell, R.E. and Bennett, N. (1993) 'Employee propensity to withhold effort: A conceptual model to intersect three avenues of research', Academy of Management Review 18: 429-456.

La Porta, R., Lopez-deSilanes, F. and Shleifer, A. (1999) 'Corporate ownership around the world', Journal of Finance 54: 471-517.

La Porta, R., Lopez-deSilanes, F., Shleifer, A. and Vishny, R.W. (2002) 'Investor protection and corporate valuation', Journal of Finance 54: 1147-1170. 
Lipton, M. and Lorsch, J.W. (1992) 'A modest proposal for improved corporate governance', Business Lawyer 48: 59-77.

Macey, J.R. and O'Hara, M. (2003) 'The corporate governance of banks', Economic Policy Review 9: 91-107.

Marris, R. (1964) The Economic Theory of Managerial Capitalism, New York: The Free Press.

McConnell, J.J. and Servaes, H. (1990) 'Additional evidence on equity ownership and corporate value', Journal of Financial Economics 27: 595-612.

Penrose, E. (1959) The Theory of the Growth of the Firm, Oxford: Basil Blackwell.

Rosenstein, S. and Wyatt, J.G. (1990) 'Outside directors, board independence, and shareholder wealth', Journal of Financial Economics 26: 175-191.

Shaw, M.E. (1981) Group Dynamics: The Psychology of Small-Group Behavior, New York: McGraw-Hill.

Shleifer, A. and Vishny, R. (1986) 'Large shareholders and corporation control', Journal of Political Economy 94: 461-488.

Short, H., Keasey, K., Wright, M. and Hull, A. (1999) 'Corporate governance: From accountability to enterprise', Accounting and Business Research 29: 337-352.

Singh, H. and Harianto, F. (1989) 'Management-board relationships, takeover risk, and the adoption of golden parachutes', Academy of Management Journal 32: 7-24.

Vafeas, N. (1999) 'Board meeting frequency and firm performance', Journal of Financial Economics 53: $113-142$.

Williamson, O. (1964) The Economics of Discretionary Behavior: Managerial Objectives in a Theory of the Firm, Englewood Cliffs, NJ: Prentice Hall.

Yermack, D. (1996) 'Higher market valuation of companies with a small board of directors', Journal of Financial Economics 40: 185-211.

Yuengert, A. (1993) 'The Measurement of efficiency in Life Insurance: Estimates of a Mixed NormalGamma Error Model', Journal of Banking and Finance 17: 483-496.

\section{About the Authors}

Jennifer L. Wang is Associate Professor of Risk Management and Insurance Department at National Chengchi University, Taiwan.

Vivian Jeng is Assistant Professor of Risk Management and Insurance Department at National Chengchi University, Taiwan.

Jin Lung Peng is Assistant Professor in the Risk Management Department at Shih Chien University, Taiwan. 